\title{
ENSURING OUR FUTURE
}

\section{The Fabric of Childhood in Australian Society}

\author{
National Conference
}

\author{
Hilton International Hotel \\ ADELAIDE
}

15 -17 May, 1991

\section{PROGRAM}

Day 1: Wednesday 15 May, 1991

9.30am Registration

10.30am Official Opening

11.00am Keynote Address: Ms Maalfrid Flekkoy Future options for children

$1.30 \mathrm{pm}$ Keynote Address Dr Don Edgar

The growth of competence

3.00-5.00pm 3 concurrent sessions.

Dr Jacki Goodnow, Macquarie University

Reflections of the family environment

Sr Patricia Pak-Poy, Adelaide

Learning in a multicultural environment

Ms Jan Carter, Brotherhood of St. Lawrence

The needs of children and the family

Evening: Reception.
Day 2: Thursday, 16 May, 1991

9.00am 3 concurrent sessions

Dr Graham Martin, Flinders University

Family and societal values

Dr Lois Foster, Bureau Immigration

Research Future Australians

Prof Richard Chisholm, Univ. of NSW

Legislation and children

$11.30 \mathrm{am}$ Keynote Address

Ms Lois O'Donohue

Cultures old and new

Afternoon

Entertainment by Dorinda Hafner

Poster sessions

Hyde Park Corner - delegates have their say.

Evening: Conference Dinner
Day 3: Friday, 17 May, 1991

9.00am 3 concurrent sessions Mr Garth Boomer, Adelaide Learning for the future

Dr Fernando Monckeberg, Chile

Urbanisation and the child

Prof Lois Bryson, Newcastle

Policy making for children

11.30am Keynote Address

Dr Deborah Phillips

Children of the future - caring

now for tomorrow

$2.00 \mathrm{pm}$ Closing Session

Ms Maalfrid Flekkoy

Future options revisited

Closing Address

Ms Anne Deveson

Pulling the threads together,

images of childhood

Completion and presentation of

the wall hanging made by South

Australian children.

\section{KEYNOTE SPEAKERS}

Ms Maalfrid Flekkoy

UNICEF Senior Scholar, Intemational Child Development Centre,

Florence, Italy.

Formerly, Norway's first Ombudsman for Children

Dr Don Edgar

Director, Australian Institute of Family Studies

Melboume, Victoria

Ms Lois O'Donohue CBE AM

Chairperson,

Aboriginal and Torres Strait Islander Commission,

Canberra

Dr Deborah Phillip

Assistant Professor of Psychology

University of Virginia, Virginia, USA

Ms Anne Deveson

Journalist, Film Maker, Social Commentator

Sydney, NSW

\section{CONFERENCE AIMS}

- focus on the family, economic and multicultural environment of the Australian child

explore the positive and negative aspects of the child's relationship with the physical and human environment

communicate across disciplines, organisations, people and systems about children and childhood

highlight and forecast the nature of children's service into the 21st century

identify those aspects of childhood which contribute positively to growth and development

hear from children those things they value about their childhood

\section{Enquiries to:}

Festival City Conventions

PO Bax 986

NORWOOD SA 5067

Tel:(08) 3631307 Fax:(08) 3631604 


$$
\text { 1. CHILDREN AUSTRALIA }
$$
AUSTRALIA 